\title{
CORRESPONDENCE
}

\section{ON DATING THE BRITISH TERTIARY IGNEOUS PROVINCE}

SIR,--In the past, it has been conventional to consider the rocks of the British Tertiary igneous province as all of closely similar ages. The recent letter in the Geological Magazine by Miller and Brown (1963) indicates that the Mourne granite is somewhat older than the Antrim lavas. Reflection on this and other relevant findings leads to an apparently anomalous position.

The present situation may be summarized as follows :-

(1) the Gl granite of the Mourne Mountains is $75( \pm 7)$ million years old (Miller and Brown, 1963) i.e. close to the Cretaceous-Tertiary boundary on Kulp's time scale (1960).

(2) the G1 granite of Lundy is 50-55 million years old (Miller and Fitch, 1962) i.e. Eocene on Kulp's scale.

(3) the cones and pollen from the interbasaltic horizons of the Antrim and Scottish plateau basalts are of late Miocene to early Pliocene age (Simpson in Eyles, 1952, p. 4) i.e. about 20 million years ago.

(4) the remanent magnetization of the basalt lavas of Skye suggest a lower Miocene age. Preliminary magnetization data on the gabbros of Skye, Ardnamurchan, and Rhum give a similar age (Khan, 1960, p. 60).

(5) the basalt lavas of Iceland were erupted in two stages, Eocene or possibly Oligocene and Pliocene to Present day, and that between these two periods the Thulean land area was broken up and the North Atlantic Ocean formed (Hawkes, 1938, p. 295).

Unpublished and published (1960a and $b$ ) data by the writer indicate that (i) the granites and granophyres of the Mourne and Carlingford complexes appear to be of the same age, on account of their petrological and other similarities; (ii) the Carlingford granophyres are later than the plateau basalt lava flows at Carlingford which lavas are considered to be outliers of the Antrim plateau basalts.

Not all these statements are mutually compatible. The dilemma created needs further work on the relative and absolute ages of the rocks of the whole province before it can be solved. Such data would also greatly assist in the problem of the origin of the Thulean province; whether or not it may have been associated with the drifting apart of the American and European continents; and whether or not it may have been also associated with the Oligocene-Miocene movements of the Alpine orogeny.

\section{REFERENCES}

EylEs, V. A., 1952. The composition and origin of the Antrim laterites and bauxites. Mem. Geol. Surv. U.K.

Hawkes, L., 1938. The age of the rocks and topography of middle Northern Iceland. Geol. Mag., 75, 289-296.

Khan, M. A., 1960. The remanent magnetization of the basic Tertiary igneous rocks of Skye, Inverness-shire. J. Geophys.,3, 45-62.

KuLP, J. L., 1960. The geological time-scale. 21st Int. Geol. Congr., III, 18-27.

LE BAS, M. J., 1960a. The petrology of the layered basic rocks of the Carlingford complex, Co. Louth. Trans. roy. Soc. Edinb., 64, 169-200.

- 1960b. in Charlesworth, J. K., et al. The geology of North-East Ireland. Proc. Geol. Ass., Lond., 71, 429-459.

Miller, J. A., and P. E. Brown, 1963. An absolute age determination on the Mourne Mountain granite. Geol. Mag., 100, 93.

Miller, J. A., and F. J. Fitch, 1962. Age of Lundy granites. Nature, 195, $553-555$.

DePARTMENT OF GEOLOGY,

M. J. LE BAS.

UNIVERSITY OF LEICESTER.

25th April, 1963. 
SIR,-I happened to see the proofs of this letter and hope I may be allowed to contribute. Some of the further information Dr. Le Bas seeks is now in press for the Mineralogical Magazine in a short paper Dr. J. A Miller and I submitted before the date of the letter (from Miller and Brown) referred to above by Dr. Le Bas. It gives preliminary radiometric ages of some Arran rocks and mentions similar ages for some other Scottish rocks. These generally confirm a Palaeocene and Eocene age for the main igneous activity, according to time scales currently in use. We mentioned the evidence apparently conflicting with this conclusion (points (3) and (4) of Dr. Le Bas' letter) and implicitly rejected it in favour of the radiometric evidence. It may be worth examining these discrepencies in more detail.

The conflict arises because of generally accepted correlations of plateau basalts (and various plant beds) throughout the British province. This assumption will be continued here but may have to be abandoned. The only age by marine beds in Britain makes them post Senonian. In Denmark, however, basaltic and andesitic tuffs (and the only ones, I think) have long been known near the base of the plastic clays (Eocene) just above the Selandian (Palaeocene). In Greenland the main plateau basalts are pre-Kap Dalton (i.e. pre-Late Eocene (Hassan, 1953) or pre-Middle Oligocene (Sorgenfrei, 1940, p. 85); but the range of igneous activity extends considerably both upwards and downwards stratigraphically.

Until recently palaeobotanical estimates of Tertiary ages have been unreliable. Heer in 1868 attributed floras throughout the Arctic (Greenland, North America, Iceland, Spitsbergen) to the Miocene and, following Forbes, he also correlated the well known Mull leaf beds with Swiss Miocene (Oeningen) beds.

J. S. Gardiner (1887) strongly contested this view after a re-examination of the evidence and a collection of more material. He concluded an age low down in the Eocene and extended this argument to the neighbouring Arctic plant beds, and this age was generally accepted (e.g. by Seward). Many more palaeobotanical studies have been made and one of the most recent of these described the microflora associated with the well known plant beds of Spitsbergen (Manum, 1962). These are found above a succession with marine molluscan faunas of probable Palaeocene to Lower Eocene age (Ravn, 1922). Manum concluded that the microflora does not yield a precise age but is consistent with the palaeozoological evidence (i.e. Lower Tertiary). From similar studies of Icelandic microfloras Pflug in 1956 and later suggested an age within Upper Palaeocene to Lower Oligocene limits. Manum critically compared similar Icelandic samples with the Spitsbergen material and found no reason to disagree. In a study of three Irish pollen-bearing deposits Watts (1962) concluded an age for the interbasaltic clays (with the poorest flora) to fall between that of the Lough Neagh Clays (Lower or Middle Oligocene) and Ballymacadam Clays (? Late Eocene). This was based on comparisons with German brown coals and showed little similarity with the well-dated Lower Miocene ones.

In the meantime Simpson had announced at the British Association in 1951 a late Oligocene or Miocene age for the Mull and Ardnamurchan beds (and in 1952 a Miocene or Pliocene age for the inter-basaltic clays of Ireland). The evidence on which this age was inferred was published posthumously (1961) with a description of two microfloras yielding entirely new species, altogether seventy-one in number, There is minimum discussion of his age conclusions which are not based on any specific correlation, but in relation to Reid and Chandler's (1933) climatological and regional affinity trends. The percentages supporting the combined East Asian-American affinity trend, and to which new data were fitted, are : [no Palaeocene], 2 Eocene, 1 Oligocene, [no Miocene], 4 Pliocene and Pleistocene; and on this evidence alone a late Oligocene or Miocene age is concluded. An adequate case for a Miocene age has not yet been made and it thus seems that on purely palaeontological grounds the various plant horizons below and within the various basalts could all be Palaeocene and Eocene-possibly extending up to Oligocene. There 
is considerable hope that radiometric ages of basalts in particular will shortly give these floras greater stratigraphical relevance.

Khan's palaeomagnetic pole position of $70^{\circ} \cdot 8\left( \pm 3^{\circ} \cdot 8\right) \mathrm{N}$ and $159^{\circ} \cdot 6$ $\left( \pm 5^{\circ} \cdot 1\right) \mathrm{E}$, of Skye lavas and other rocks, is based on impressive evidence (1960). In addition he assumed a Miocene age which he did not argue in detail. He had taken into consideration both floral (especially Simpson's) evidence and a comparison with pole positions of eleven other European and Icelandic rocks. Of the few whose positions are reliably defined, none are well dated. Thus any further (radiometric) evidence of the age of these rocks will allow the pole positions already obtained to be used more reliably.

The new data are only the beginnings of what may become a flood of radiometric results on most igneous rocks, and the time scale, as well as the stratigraphy, may well need revising. In the meantime, however, there seems little reason to doubt that the main Thulean igneous events of Scotland were Lower Tertiary. This could have accompanied a time of North Atlantic extension, to be followed by a compressive phase evidenced not only in Alpine and western Europe but also most markedly in Western Spitsbergen and North-east Greenland. Again, in Pliocene and Quaternary times, Iceland and Spitsbergen became volcanically active.

SedgWick Museum,

W. B. HARLAND.

CAMbridge.

9th May, 1963.

\section{SELECTED REFERENCES}

GARDiner, J. S., 1887. On the Leaf-beds and Gravels of Ardtun, Carsaig, etc., in Mull. With notes by G. A. C. Cole. Quart. J. geol. Soc. Lond., 43, 270-300.

Hassan, M., 1953. Tertiary faunas from Kap Brewster, East Greenland. Medd. Gronland, 111, (5).

Hefr, O, 1870. Die miocene Flora und Fauna Spitzbergens. Kongl. Svenska Vetensk. Akad. Handl., 8, No. 7, Stockholm, 1870.

KHAN, M. A., 1960. The remanent magnetization of the basic Tertiary igneous rocks of Skye, Inverness-shire. Geophys. J., 3, 45-62.

Manum, S., 1962. Studies in the Tertiary flora of Spitsbergen, with notes on Tertiary floras of Ellesmere Island, Greenland, and Iceland. Norsk Polarinstitutt Skr. Nr., 125, 1-127.

RavN, J. P. T., 1922. On the mollusca of the Tertiary of Spitsbergen. $S k r$. norsk Polarinst., No. 2.

Reid, E. M. and M. E. J, ChANDler., 1933 . The London Clay Flora. British Museum (Nat. Hist.), London.

Simpson, J. B., 1961. The Tertiary Pollen-Flora of Mull and Ardnamurchan. (Comparison with other European Tertiary floras by I. M. Simpson). Trans. roy. Soc. Edinb., 64, No. 16, 421-468, pls.

Sorgenfrei, T., 1940. Marint Nedre-Miocoen i Klintinghoved paa Als. Danm. geol. Unders., II, Raekke No. 65.

WatTs, W. A., 1962. Early Tertiary Pollen Deposits in Ireland. Nature, 193, 600 .

SIR,--In view of new data now available we would like to comment on several matters relevant to the letter from Dr. Le Bas concerning age relationships in the British Tertiary igneous province. In the past it may have been convention to consider the rocks of the province as all of closely similar age but this is not supported by recent potassium-argon age determinations. Much, of course, depends on what is meant by closely similar ages. Thus, considering for the moment intrusive rocks, which have been dated by the separation of minerals suitable for the method, the Mourne granite centre yielded $75 \pm 7$ million years (Miller and Brown, 1963), the Arran granites an 
average of around 60 million years (Miller and Harland, in the press), the Lundy G1 granite 50-55 million years (Miller and Fitch, 1962), and a single determination on the quartz-monzonite of Centre 3 Ardnamurchan $55 \pm 6$ million years (Miller and Brown, in the press). We regard these results as indicative of real variations in age and would not agree that they necessarily constitute an anomaly.

Concerning the age of the Antrim basalts and the interbasaltic horizons, new whole-rock potassium-argon age determinations have been made on thirteen specimens taken from the lower to the upper lava series Despite a large scatter of individual determinations the results give a strong indication that the volcanic activity took place in Palaeocene or Eocene times and the mean age is 74 million years. Preliminary results on the Mull basalts give a similar age. There is thus reason for believing that the Antrim interbasaltic horizons are of greater age than late Miocene or early Pliocene (about 20 million years) suggested by Simpson (in Eyles, 1952) on palynological evidence. Similarly the age determinations suggest that Mull lavas are predominantly older than the late Miocene age also put forward on the basis of palynological studies (Simpson, 1951). Also, though the absolute age of the Carlingford granophyres has not yet been determined they could be of similar age to the Mourne granites and, within the limits of experimental errors, both could be younger than at least the lower part of the Antrim lavas. It must also be said that there could, on the evidence of the basalt ages, be some relationship between the Tardree rhyolite and the granites, a question which was discussed in our previous letter (Miller and Brown, 1963).

Concerning the age of the Icelandic basalts it is relevant that an extensive palynological study of the interbasaltic horizons in the lava plateau has been made by Pflug $(1956,1959)$ and leaf impressions have been analysed by Askelsson $(1954,1956,1957)$. A lower Tertiary, probably Eocene, age is suggested for the lower horizons. Pollen analysis of an interbasaltic horizon high in the basalt plateau suggests a pause in activity from Upper Oligocene to Lower Pliocene (Schwarzbach and Pflug, 1957).

Khan (1960) has suggested that the basic igneous rocks of Skye, Rhum, and Ardnamurchan are of similar ages. We have no reason to doubt this view and would point out that if this be true, these rocks would all be slightly older than the $55 \pm 6$ million years yielded by the quartz-monzonite from Ardnamurchan, and therefore lower Tertiary in age.

Most of the incompatibilities pointed out by Dr. Le Bas appear to be resolved by the information given here and no doubt a clearer picture will emerge as results of greater accuracy on basaltic material become available. It is perhaps a little premature to anticipate these results in further speculative discussion.

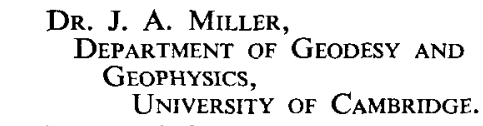

\author{
Dr. P. E. Brown, \\ DePARTMENT OF GeOLOGY, \\ UNIVERSITY OF SHEFFIELD.
}

9th May, 1963.

\title{
REFERENCES
}

Askelsson, J., 1954. Myndir úr jardfrædi Îslands II. (English summary The Geology of Iceland II, Some Tertiary plants from Iceland) Náttúrufradingurinn, 24, 92-6.

-1956. Myndir úr jardfrædi Íslands IV. (English summary The Geology of Iceland IV, On Some Tertiary plants) Nätú rufredingurinn, 26, 44-8.

-1957. Myndir úr jardfrædi f́slands VI. (English summary The Geology of Iceland VI, On 3 Tertiary plants not described before in Iceland) Náttúrufredingurinn, 27, 24-9. 
EyLES, V. A., 1952. The composition and origin of the Antrim laterites and bauxites. Mem. Geol. Surv U.K.

KHAN, M. A., 1960. The remanent magnetization of the basic Tertiary igneous rocks of Skye. Geophys. J., 3, 45-62.

Miller, J. A., and F. J. Fitch, 1962. Age of the Lundy Island Granites. Nature, 195, 553.

Miller, J. A., and P. E. Brown. 1963. An absolute age determination on the Mourne Mountain granite. Geol. Mag., 100, 93.

Pflug, H. D., 1956. Sporen und pollen von Tröllatüga (Island) und ihre Stellung zu den pollenstratigraphischen Bildern Mitteleuropas. Neues Jb. Geol. Abh., 102, 409-30.

1959. Sporenbilder aus Island und ihre stratigraphische Deutung. Neues Jb. Geol. Abh., 107, 147-172.

Schwarzbach, M., und H. D. Pflug, 1957. Das Klima des jungeren Tertiärs in Island. Neues Jb. Geol Abh., 104, 279-298.

Simpson, J. B., 1951. The age of Tertiary vulcanicity in Scotland. British Assoc. for Adv. Sci. Edinburgh Meeting Programme, p. 63.

\section{REVIEWS}

Glaciers and SNOWfields in Norway. By Adolf Hoel and Werner WERENSKIOLD. Norsk Polarinstitutt Skrifter, Nr. 114, $1962.291 \mathrm{pp}$. Folder containing 8 maps. N.Kr. 40.00 .

Glaciological Bibliography of Norway. By Adolf Hoel and Johannes NoRVIK. Norsk Polarinstitutt Skrifter, Nr. 126, 1962. 242 pp. N.Kr. 30.00 .

The first of these two volumes aims to give a general description of the glaciers of Norway and her dependencies and to report on the glaciological work conducted over many decades by the authors and their collaborators. The second, planned in conjunction, collects the bibliographic material on Norwegian glaciers. Apart from the Norwegian Antarctic territories (which are mentioned extremely briefly in the first volume and are specifically excluded from the second), the result is a compilation that no-one interested in Norwegian glaciers can afford to ignore.

The first volume starts with a short history of glaciology in Norway, and then gives a description of the glaciers of Norway, the maps that are available, the types of glaciers, their area, number and fluctuations. Next there is a chapter on benefits derived from glaciers for water-power, routes for traffic, and sources of ice for commercial purposes. After this the rest of the volume, a little over half the total length, is devoted to the personal work of the authors and their collaborators. This is itself divided into two sections, the first concerns work in Jotunheimen, where a general survey of the glaciers was carried out and two particular glaciers, Hellstugubreen and Tverråbreen, were studied in detail during the period 1927-48. On Hellstugubreen the work consisted of survey, measurement of ablation and glacier flow, frontal retreat, and studies on the discharge of the glacier stream. On Tverrabbreen the work was more concentrated on the snout area, and detailed contour maps of the snout in six different years are among the maps in the folder. The second part of the personal work consists of a study of glaciers in northern Norway by Hoel. Many more glaciers have been investigated, and the detail of study of any individual glacier is correspondingly less, but for anyone interested in these glaciers, the work will be invaluable. Throughout there is a great interest in place names and their significance, and in early travellers' descriptions. 